\title{
Influence of stocking density on water quality and growth performance of whiteleg shrimp (Litopenaeus vannamei) reared in fiberglass tanks, without water exchange
}

\section{Tu P. C. Nguyen ${ }^{1 *}$, Ha N. Nguyen ${ }^{2}$, Tinh T. Phung ${ }^{1}, \&$ Nhan T. Dinh ${ }^{1}$}

${ }^{1}$ Faculty of Fisheries, Nong Lam University, Ho Chi Minh City, Vietnam

${ }^{2}$ Research Institute for Biotechnology and Environment, Nong Lam University, Ho Chi Minh City, Vietnam

\author{
ARTICLE INFO \\ Research Paper \\ Received: November 08, 2019 \\ Revised: December 05, 2019 \\ Accepted: December 26, 2019 \\ Keywords \\ Density effect \\ Growth performance \\ Shrimp Litopenaeus vannamei \\ Water quality \\ ${ }^{*}$ Corresponding author \\ Nguyen Phuc Cam Tu \\ Email: npctu@hcmuaf.edu.vn
}

\begin{abstract}
The present study evaluated the effects of stocking density on water quality parameters, growth performance and survival rate of white leg shrimp Litopenaeus vannamei, reared in fiberglass tanks, without water exchange. Three stocking densities (50, 100 and $200 \mathrm{shrimp} / \mathrm{m}^{2}$ ) were tested. Each treatment consisted of three replicate fiberglass tanks (500 L). The shrimp were fed ad libitum four times per day with a commercial pellet (40-42\% protein). After an 8-week trial, concentrations of nutrients in the culture tanks showed an increasing linear relationship with increasing stocking density. The growth performance of shrimp in low stocking densities was significantly greater than that in high stocking densities. The results from this study demonstrate that with increasing the stocking density the production of shrimp increased but in a low final weight and survival compared to low stocking density.
\end{abstract}

Cited as: Nguyen, T. P. C., Nguyen, H. N., Phung, T. T., \& Dinh, N. T. (2019). Influence of stocking density on water quality and growth performance of whiteleg shrimp (Litopenaeus vannamei) reared in fiberglass tanks, without water exchange. The Journal of Agriculture and Development 18(6), 14-22.

\section{Introduction}

In Vietnam, since the 1990s, shrimp has become an important brackish species in farming and the main product of seafood export. The area under farming was increased annually at a high growth rate. Addition to increased farming area, the farm production of shrimp in Viet Nam was also diversified in cultured systems and intensified in stocking density, inputs and management (Nguyen et al., 2019). Although shrimp farming has contributed significantly to the socioeconomic development of the country, it has increased in pollution of land and water and resulted in the degradation of the environment.

One of the major environmental concerns relate to intensive aquaculture is the discharge of nutrient-rich effluents into the water bodies. During the shrimp farming cycle, solid wastes (uneaten food and feces) settled at the pond bottom and negatively impact on the water quality. The nutrient retention by shrimp ranged from between $6 \%$ and $30 \%$ for carbon (C), $17 \%$ and $45 \%$ for nitrogen $(\mathrm{N})$, and $6.1 \%$ and $21.3 \%$ for phosphorus (P), whereas most of the $\mathrm{N}(24-49 \%)$, $\mathrm{P}(24-84 \%)$, and $\mathrm{C}(65 \%)$ not recovered in harvested shrimp accumulated in the culture system (Avnimelech \& Ritvo, 2003; Sahu et al., 2013). Boopathy et al. (2007) reported that concentrations of chemical oxygen demand, total solid and total ammonia nitrogen in shrimp wastewater sludge might reach 1,201 mg/L, 13,100 mg/L and $102 \mathrm{mg} / \mathrm{L}$, respectively, exceeding the limits of wastewater discharge standard. 
The density-dependence in growth and mortality in shrimp were reported in several works (Allan \& Maguire, 1992; Moss \& Moss, 2004; Legarda et al., 2018). An increase in stocking density from 5 to $40 \mathrm{shrimp} / \mathrm{m}^{2}$ had no effect on the survival of Penaeus monodon and water quality, but growth declined and yield increased as density increased (Allan \& Maguire, 1992). Similarly, as the stocking density of shrimp $P$. stylirostris increased from 1 to $30 \mathrm{shrimp} / \mathrm{m}^{2}$, the shrimp weight and survival rate decreased significantly and the amount of wastes produced was relative to the stocking density (Martin et al., 1998). $\mathrm{Yu}$ et al. (2009) reported that increasing stocking densities reduced the growth performance and survival rate of cultured shrimp and water quality deterioration. Similarly, Arnold et al. (2009) and Arambul-Muñoz et al. (2019) found that density-dependent growth and survival in intensive shrimp culture could be mainly due to a combination of factors, including a decrease in the availability of natural food sources and space, an increase in cannibalism, decrease in water quality and accumulation of undesirable sediments.

The main objective of the farmers in Viet Nam is to maximize profit per unit area, usually leading to more environmental problems. However, the high density of shrimp may be far over the carrying capacity of the pond. An inverse relationship between stocking density and shrimp growth in Viet Nam was reported (Nguyen et al., 2013), but there has been limited research on this topic, particularly at a density higher than 100 shrimp $/ \mathrm{m}^{2}$. Therefore, this study was carried out to assess the effects of three stocking densities of whiteleg shrimp (Litopenaeus vannamei) on (i) water quality, and (ii) growth performance and feed utilization of shrimp.

\section{Materials and Methods}

\subsection{Shrimp, seawater, and feed}

This study was performed at the experiment farm, Faculty of Fisheries, Nong Lam University, Ho Chi Minh City, Vietnam. Juvenile whiteleg shrimp L. vannamei $(0.82 \pm 0.07 \mathrm{~g})$ were purchased from a private hatchery nearby the university. Shrimp were transported in 45-L styrofoam box equipped with air pumps to the experiment farm. Shrimp were acclimatized in $1 \mathrm{~m}^{3}$-fiberglass tank to the experimental condition for one weeks and fed commercial pellets thrice per day.
The culture water salinity of $15 \%$ in the trial was made by diluting natural seawater with tap water, disinfected by chlorine of $30 \mathrm{ppm}$ for 3-4 days and neutralized with sodium thiosulfate to remove chlorine residue before use.

Three size classes of commercial feed produced by C.P. Viet Nam Corporation (Bien Hoa, Dong Nai, Viet Nam) were utilized according to different shrimp's growth stages.

\subsection{Experimental procedure and management}

The experimental design was completely randomized with three treatments (three shrimp densities): 50, 100 and $200 \mathrm{shrimp} / \mathrm{m}^{2}$ (abbreviation of D50, D100 and D200, respectively), each treatment repeated 3 times. The experiment was conducted in nine 500 L-fiberglass tanks, coupled with a biofilter, with a water volume maintaining at $400 \mathrm{~L}$. The tank was equipped with an air-stone and two 100-W aquarium thermostat heaters.

Every tank had an associated, $10 \mathrm{~L}$ biofilter $(\phi 26.4 \times 24.6 \mathrm{~cm})$, made from a plastic bucket. Biofilter design using downflow trickling filter was placed above the shrimp tank. Water went into the biofilter by way of a $27 \mathrm{~mm}$ airlift pipe, moving from the base of the tank. Water from the airlift passed through a fine mesh on the top of the biofilter, then flowed over the crushed coral media (media depth of $18 \mathrm{~cm}$ ) and out an array of $1 \mathrm{~cm}$ holes (drilled in the bottom) and back into the shrimp tank. During the experiment, water was recirculated with no water exchange, the only freshwater added was that needed to compensate for evaporation and sampling.

The experiment lasted for 8 weeks. During the experiment, the shrimp were hand-fed to apparent satiation four times per day (at 7:00, 12:00, 17:00 and 22:00 h) using circular feeding trays $(\phi 40 \mathrm{~cm})$. One hour after feeding, uneaten feed and feces were removed. To estimate the feed intake, all uneaten feed found in feeding trays was collected, dried in the oven, and weighted.

\subsection{Water sampling and analyzing}

Water quality variables such as temperature, $\mathrm{pH}$, and dissolved oxygen (DO) were measured twice daily (07:00 - 08:00 and 16:00 - 17:00) by HP3040 pH/mV/Temp. Meter and Milwaukee MW 600 DO Meter, respectively. Routine 
bi-weekly water sampling was done at 07:00 from each tank, kept in an ice box, transferred to the laboratory of Faculty of Fisheries, Nong Lam University within $2 \mathrm{~h}$ and analyzed within $24 \mathrm{~h}$. Water quality parameters, e.g., alkalinity, total suspended solids (TSS), nitrogen compounds (ammonia $(\mathrm{TAN})$, nitrite $\left(\mathrm{NO}_{2}-\mathrm{N}\right)$, nitrate $\left(\mathrm{NO}_{3}-\mathrm{N}\right)$, total Kjeldahl nitrogen $\left.(\mathrm{TKN})\right)$, phosphorus (total and soluble reactive phosphorus (TP and SRP)) and total organic carbon (TOC) were analyzed following the standard methods for water and wastewater analysis (APHA, 2012). Alkalinity and TSS were determined by titration method $(2320 \mathrm{~B})$ and filtered and dried at $103-105^{\circ} \mathrm{C}(2540 \mathrm{D})$, respectively. Levels of TAN, $\mathrm{NO}_{2}-\mathrm{N}, \mathrm{NO}_{3}-\mathrm{N}$ and TKN were analyzed by phenate method (4500$\mathrm{NH}_{3}$ F), colorimetric method $\left(4500-\mathrm{NO}_{2}-\mathrm{B}\right)$, cadmium reduction method $\left(4500-\mathrm{NO}_{3}-\mathrm{E}\right)$ and macro-Kjeldahl method (4500-Norg B), respectively. While levels of TP digested by alkaline potassium persulfate and SRP were determined by ascorbic acid colorimetric method (4500-P E), respectively. Water samples for TOC were kept frozen at $-18 \pm 2^{\circ} \mathrm{C}$, transported to the Advanced Technology Laboratory, Can Tho University, Can Tho City, Viet Nam and analyzed by LAR's TOC analyzer.

\subsection{Calculations and statistical analysis}

Weekly weight gains (WG), specific growth rate (SGR), feed conversion ratio (FCR) and survival rate $(\mathrm{SR})$ were evaluated as follows:

Weekly weight gain $(\mathrm{WG}, \mathrm{g} /$ day $)=\frac{\mathrm{W}_{\mathrm{f}}-\mathrm{W}_{\mathrm{i}}}{\Delta \mathrm{t}}$

Specific growth rate $(\mathrm{SGR}, \% /$ day $)=$

$$
\frac{\ln \mathrm{W}_{\mathrm{f}}-\ln \mathrm{W}_{\mathrm{i}}}{\Delta \mathrm{t}} \times 100
$$

Feed conversion ratio $(\mathrm{FCR})=$

$$
\frac{\text { feed consumed (dry matter) }}{\text { wet weight gain }}
$$

Survival rate $(\mathrm{SR}, \%)=$

$$
\frac{\text { final number of shrimp }}{\text { initial number of shrimp }} \times 100
$$

where $\mathrm{W}_{\mathrm{f}}$ and $\mathrm{W}_{\mathrm{i}}$ represent the final and initial body weights of shrimp individuals in each tank, respectively $(\mathrm{g})$; and $\Delta \mathrm{t}$ is the duration of the experiment ( 8 weeks, equal to 56 days).

Survival rates were arcsine square root transformed but untransformed values are shown here. Water quality parameters were compared using one-way repeated measure ANOVA with treatments (stocking density) as the main factor and time as repeated measures (Gomez \& Gomez, 1984). Bonferroni test was used when differences between time and treatments were detected $(P$ $<0.05)$. Data obtained from shrimp performance (WG, SGR, FCR and SR) were analysed using one-way ANOVA to determine the effect of stocking densities. Duncan multiple range test (Duncan test) at $P<0.05$ level of significance was employed to compare mean differences between treatments. All statistical analyses were performed using IBM SPSS Statistics for Windows, Version 19.0 (Armonk, NY: IBM Corp). All data were expressed as the mean \pm standard deviation $(\mathrm{SD})$.

\section{Results and Discussion}

\subsection{Parameters of water quality}

Water temperature, $\mathrm{pH}$ and DO levels in all tanks tended to be relatively stable (Table 1) and were maintained within acceptable limits for the maximum growth of L. vannamei (Wyk \& Scarpa, 1999; MARD, 2014).

The water quality parameters monitored biweekly are given in Table 2 . No significant differences $(P>0.05)$ between treatments were found in water quality regarding TSS, alkalinity and TAN. However, significant differences $(P<0.05)$ were observed for nitrite, nitrate, TKN, SRP, TP and TOC among the treatments (Table 2). In general, levels of these parameters at a density of $50 \mathrm{shrimp} / \mathrm{m}^{2}$ showed the lowest, while the treatment 200 shrimp $/ \mathrm{m}^{2}$ provided the highest, followed by the treatment $100 \mathrm{con} / \mathrm{m}^{2}$.

The results showed that TSS concentrations were relatively low and increased significantly $(P<0.05)$ over time, on average, ranging from $1.76 \mathrm{mg} / \mathrm{L}$ at stocking to $10.2 \mathrm{mg} / \mathrm{L}$ at harvest (Figure 1). Alkalinity decreased gradually in all treatments, particularly at high stocking density, though regular adding sodium bicarbonate to maintain alkalinity (Figure 1). The recorded low alkalinity values were due to the consumption of inorganic carbon by the nitrifying bacteria (Ebeling et al., 2006). According to Chen et al. (2006), for every gram of TAN being oxidized to nitrate, about $7.07 \mathrm{~g}$ of alkalinity is consumed.

Concentrations of TAN fluctuated significantly $(P<0.05)$ between sampling times, and the high- 
Table 1. Water temperature, $\mathrm{pH}$ and DO levels (mean $\pm \mathrm{SD}$ ) of all tanks with different stocking densities

\begin{tabular}{llccc}
\hline \multirow{2}{*}{ Parameters } & \multirow{2}{*}{ Time } & \multicolumn{3}{c}{ Treatment } \\
\cline { 3 - 5 } & & D50 & D100 & D200 \\
\hline \multirow{2}{*}{ Temperature $\left({ }^{\circ} \mathrm{C}\right)$} & Morning & $29.4 \pm 1.0$ & $29.8 \pm 0.8$ & $29.3 \pm 1.0$ \\
& Afternoon & $29.8 \pm 0.8$ & $29.4 \pm 1.0$ & $29.4 \pm 0.9$ \\
\multirow{2}{*}{ DO $(\mathrm{mg} / \mathrm{L})$} & Morning & $6.52 \pm 0.27$ & $6.38 \pm 0.33$ & $6.26 \pm 0.35$ \\
\multirow{2}{*}{$\mathrm{pH}$} & Afternoon & $6.38 \pm 0.33$ & $6.35 \pm 0.31$ & $6.16 \pm 0.33$ \\
& Morning & $7.72 \pm 0.44$ & $7.71 \pm 0.10$ & $7.61 \pm 0.12$ \\
& Afternoon & $7.71 \pm 0.10$ & $7.67 \pm 0.11$ & $7.65 \pm 0.10$ \\
\hline
\end{tabular}

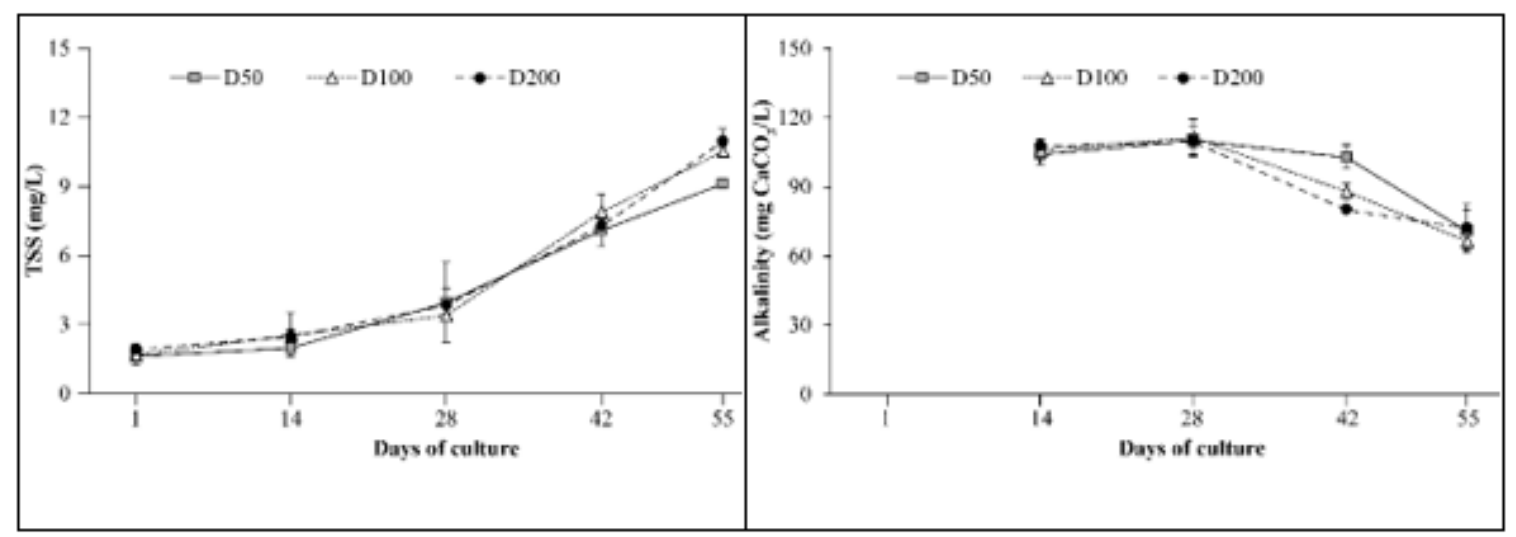

Figure 1. Effects of stocking densities on variations of levels of TSS and alkalinity in the culture of $L$. vannamei during the study. Values are means and standard deviations at sampling times $(\mathrm{n}=3)$.

Table 2. Effects of stocking densities on the water quality parameters $(\mathrm{mg} / \mathrm{L}$, except alkalinity as mg $\mathrm{CaCO}_{3} / \mathrm{L}$ ) during the study

\begin{tabular}{lcccccc}
\hline \multirow{2}{*}{ Parameters } & \multicolumn{3}{c}{ Treatment } & \multicolumn{3}{c}{ Significance $(P \text { values })^{\ddagger}$} \\
\cline { 2 - 6 } & D50 & D100 & D200 & Density & Time & Density $\times$ Time \\
\hline TSS & $4.75 \pm 3.10^{\dagger \mathrm{a}}$ & $5.21 \pm 3.60^{\mathrm{a}}$ & $5.29 \pm 3.51^{\mathrm{a}}$ & $\mathrm{ns}$ & $<0.001$ & $<0.01$ \\
Alkalinity & $96.9 \pm 17.0^{\mathrm{a}}$ & $92.9 \pm 18.9^{\mathrm{a}}$ & $92.3 \pm 17.9^{\mathrm{a}}$ & $\mathrm{ns}$ & $<0.001$ & $<0.05$ \\
TAN & $0.96 \pm 0.58^{\mathrm{a}}$ & $1.20 \pm 0.56^{\mathrm{a}}$ & $1.57 \pm 0.95^{\mathrm{a}}$ & $\mathrm{ns}$ & $<0.001$ & $\mathrm{~ns}$ \\
$\mathrm{NO}_{2}^{-}$-N & $0.26 \pm 0.32^{\mathrm{a}}$ & $0.53 \pm 0.58^{\mathrm{b}}$ & $0.80 \pm 0.87^{\mathrm{c}}$ & $<0.01$ & $<0.001$ & $<0.01$ \\
$\mathrm{NO}_{3}^{-}$-N & $16.6 \pm 5.8^{\mathrm{a}}$ & $28.1 \pm 12.2^{\mathrm{b}}$ & $40.7 \pm 23.1^{\mathrm{c}}$ & $<0.001$ & $<0.001$ & $<0.001$ \\
$\mathrm{TKN}_{\mathrm{NRP}}$ & $2.53 \pm 1.93^{\mathrm{a}}$ & $4.29 \pm 3.05^{\mathrm{b}}$ & $5.16 \pm 3.65^{\mathrm{b}}$ & $<0.01$ & $<0.001$ & $<0.001$ \\
$\mathrm{TP}$ & $1.62 \pm 0.85^{\mathrm{a}}$ & $1.91 \pm 0.93^{\mathrm{b}}$ & $2.39 \pm 1.11^{\mathrm{c}}$ & $<0.001$ & $<0.001$ & $<0.001$ \\
TOC & $4.81 \pm 3.05^{\mathrm{a}}$ & $6.11 \pm 4.17^{\mathrm{b}}$ & $7.84 \pm 5.85^{\mathrm{c}}$ & $<0.01$ & $<0.001$ & $<0.001$ \\
\hline
\end{tabular}

$\dagger$ Values represent the mean $\pm \mathrm{SD}(\mathrm{n}=15,3$ replicate $\times 5$ sampling time $)$.

Mean values in the same row with different superscript letters differ significantly (Bonferroni test, $P<0.05$ ).

${ }^{\ddagger}$ Results from one-way repeated measure ANOVA and Bonferroni test: Density = stocking densities; Time $=$ sampling time and Density $\times$ Time $=$ interaction between stocking densities and sampling time. ns: not significant $(P>0.05)$.

est peak of TAN concentrations of all treatments was observed in the treatment D200 on week 6 of the culture period $(3.7 \mathrm{mg} / \mathrm{L})$ (Figure 2$)$. Using the calculation suggested by Boyd \& Tucker (1998), toxic ammonia $\left(\mathrm{NH}_{3}\right)$ reached a maximum value of $0.185 \mathrm{mg} / \mathrm{L}$ (at highest $\mathrm{pH}$ of 7.8 and temperature of $30^{\circ} \mathrm{C}$ ), while the lethal concentration $\left(\mathrm{LC}_{50}\right)$ of $\mathrm{NH}_{3}$ to $L$. vannamei is 2.78 $\mathrm{mg} / \mathrm{L}$ (Lin \& Chen, 2001). Also, this concentration was below the $0.3 \mathrm{mg} / \mathrm{L}$ critical value for shrimp set by QCVN 02-19: 2014/BNNPTNT (MARD, 2014). 


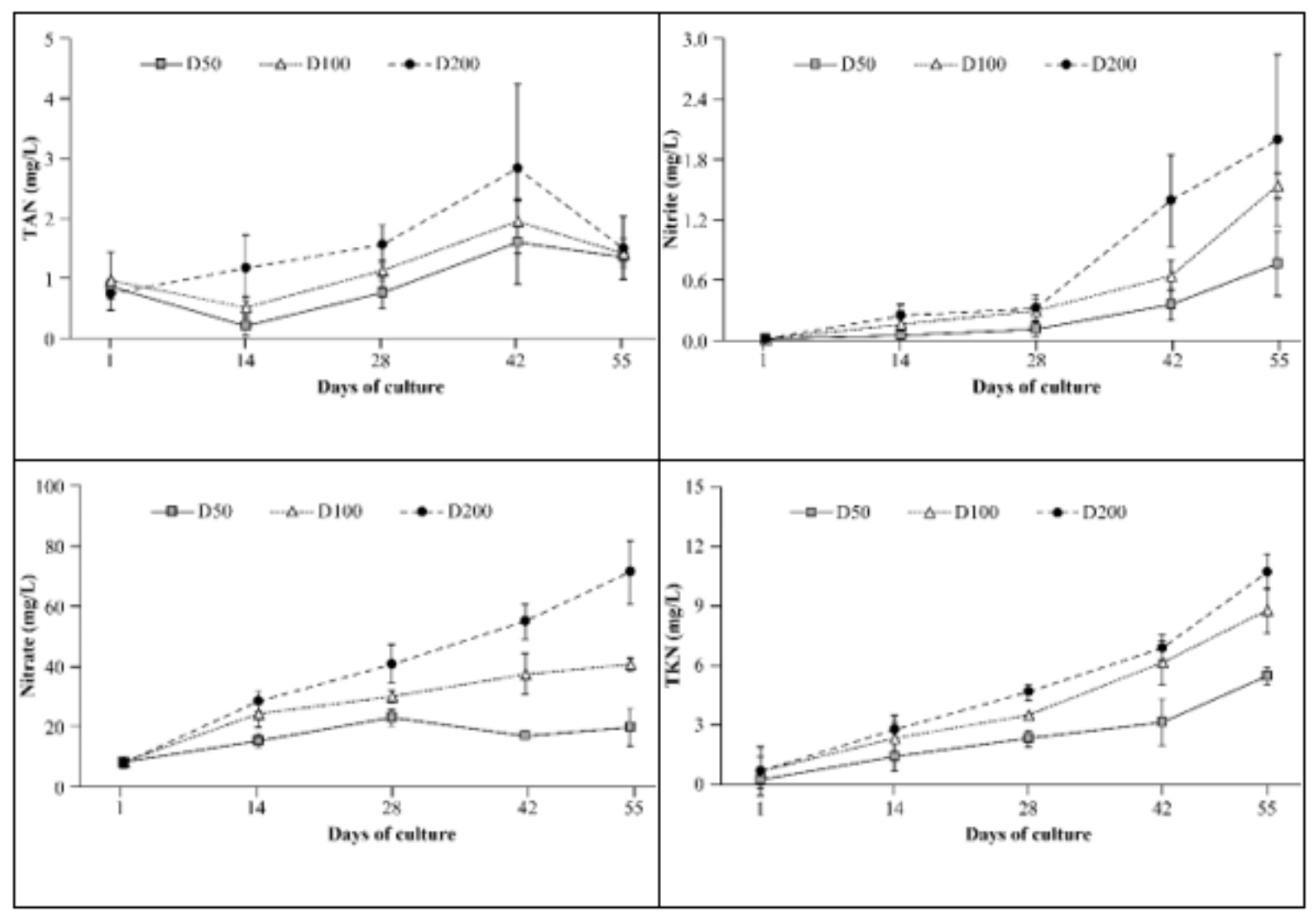

Figure 2. Effects of stocking densities on variations of concentrations of TAN, TKN, nitrite, and nitrate in the culture of L. vannamei during the study. Values are means and standard deviations at sampling times $(\mathrm{n}=3)$.

Concentrations of nitrite and nitrate significantly increased with increasing shrimp stocking density $(P<0.05)$ (Table 2$)$. Moreover, in all the treatments, there has been a sharp rise in nitrite and nitrate levels with time, reaching a peak at the end of the trial. At the end of the experiment, the highest $\mathrm{NO}_{2}-\mathrm{N}$ concentration was recorded in the treatment D200 $(2.00 \pm 0.85 \mathrm{mg} / \mathrm{L})$, followed by D100 $(1.54 \pm 0.12 \mathrm{mg} / \mathrm{L})$ and then D50 $(0.77 \pm 0.32 \mathrm{mg} / \mathrm{L})(P<0.05)$ (Figure 2$)$. The high $\mathrm{NO}_{2}-\mathrm{N}$ concentration during the last week in the treatments D100 and D200 is lower the safe level $(6.1 \mathrm{mg} / \mathrm{L}$ at $15 \%$ salinity and a $\mathrm{pH}$ of 8.0) recommended by Lin \& Chen (2003). In addition, the result showed that stocking densities had significantly affected on $\mathrm{NO}_{3}-\mathrm{N}$ levels (Table 2 and Figure 2) and $\mathrm{NO}_{3}-\mathrm{N}$ levels tended to increase over time (Table 2). The maximum nitrate concentration in the experiment, $81 \mathrm{mg} / \mathrm{L}$, exceeded the recommended target value for shrimp, $60 \mathrm{mg} / \mathrm{L}$ (Wyk \& Scarpa, 1999). However, sev- eral studies suggested that nitrate toxicity increases with a decrease in salinity (Furtado et al., 2015; Neto et al., 2019; Valencia-Castañeda et al., 2019). Kuhn et al. (2011) demonstrated that whiteleg shrimp can be reared at a salinity of $11 \%$ with $220 \mathrm{mg} / \mathrm{L}$ of nitrate for 6 weeks. According to Furtado et al. (2015), nitrate concentrations up to $177 \mathrm{mg} / \mathrm{L}$ are suitable for the rearing of $L$. vannamei in systems with bioflocs, without renewal of water, at a salinity of 23 . Neto et al. (2019) recommended the safety level of nitrate for L. vannamei cultivation is 60.05 and 127.61 $\mathrm{mg} / \mathrm{L}$ of nitrate for salinities $5 \%$ and $10 \%$, respectively.

The large decrease in TAN and the large increase in the concentration of nitrite and nitrate during the latter part of the study (Figure 2) might be related to an increase in the efficiency of the biofilters.

The concentration of TKN increased consistently in all treatments and was highest at the 


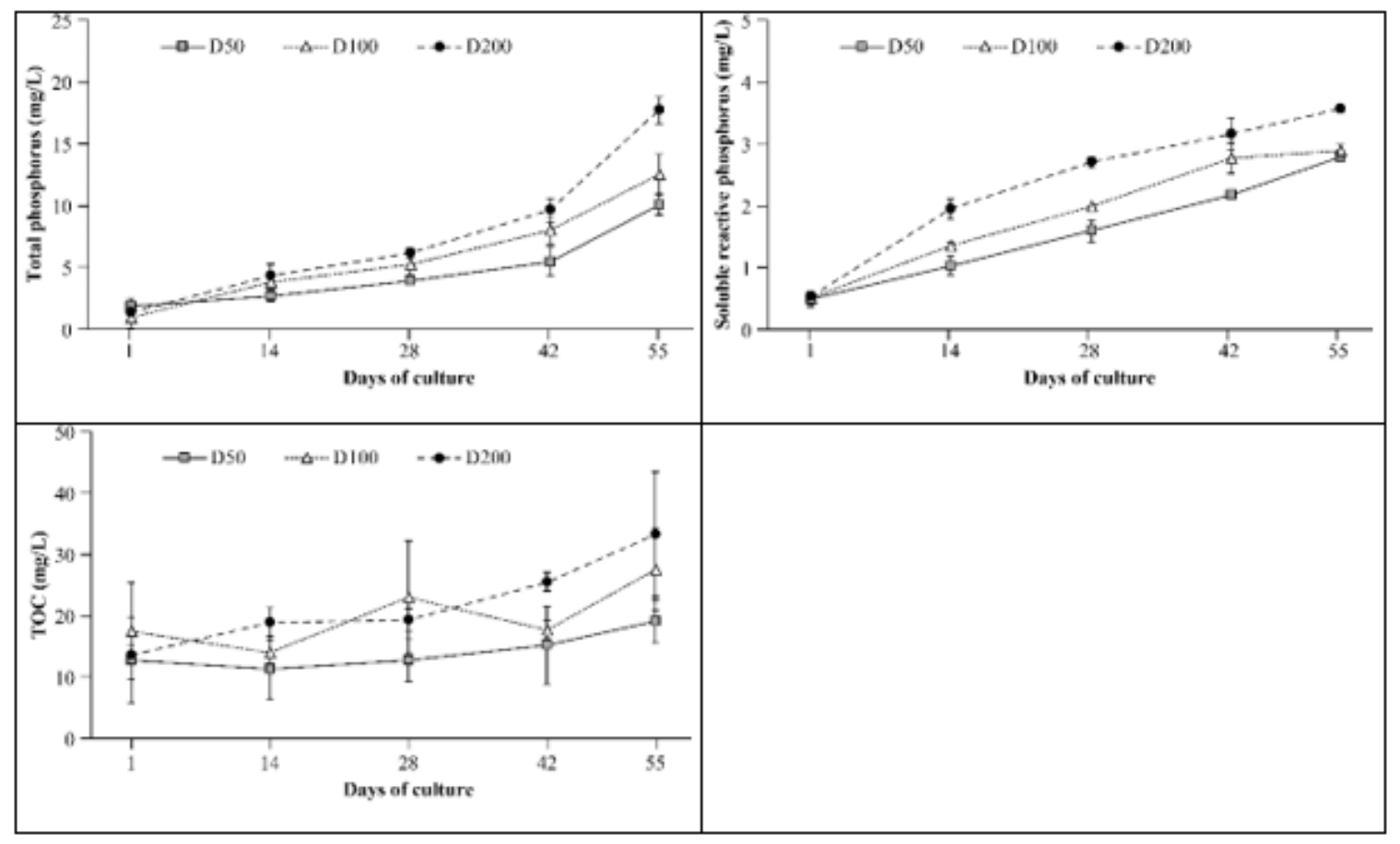

Figure 3. Effects of stocking densities on variations of TP, SRP and TOC concentrations in the culture of L. vannamei during the study. Values are means and standard deviations at sampling times $(\mathrm{n}=3)$.

end of the study; treatment D200 had the highest TKN level $(5.16 \pm 3.65 \mathrm{mg} / \mathrm{L})$, followed by $\mathrm{D} 100(4.29 \pm 3.05 \mathrm{mg} / \mathrm{L})$ and D50 was lowest $(2.53 \pm 1.93 \mathrm{mg} / \mathrm{L})$. There were significant differences in TKN among treatments (Table 2 and Figure 2). An increase in TKN level could be due to the continuous supply of protein-enriched shrimp feed and no use of nitrogen removal tools such as siphon and water exchange.

Differences in concentrations of TP and SRP between treatments were statistically significant $(P<0.05)$. The treatment D200 had the highest levels of TP and SRP $(7.84 \pm 5.85 \mathrm{mg} / \mathrm{L}$ and $2.39 \pm 1.11 \mathrm{mg} / \mathrm{L}$, respectively), followed by D100 $(6.11 \pm 4.17 \mathrm{mg} / \mathrm{L}$ and $1.91 \pm 0.93 \mathrm{mg} / \mathrm{L}$, respectively) and D50 was lowest $(4.81 \pm 3.05 \mathrm{mg} / \mathrm{L}$ and $1.62 \pm 0.85 \mathrm{mg} / \mathrm{L}$, respectively) (Table 2 ). During this 8 -week period, TP and SRP concentrations showed a steady increase over time among treatments (Figure 3).

Similarly, differences in concentrations of TOC between treatments were statistically significant $(P<0.05)$. The average level for TOC showed the highest in the treatment D200 $(22.1 \pm 8.1$ $\mathrm{mg} / \mathrm{L})$, followed by D100 (20.0 $\pm 7.2 \mathrm{mg} / \mathrm{L})$ and
D50 (14.2 $\pm 5.3 \mathrm{mg} / \mathrm{L})$ (Table 2$)$. The TOC concentration increased throughout the experiment and reached 33.3, 27.5 and $19.1 \mathrm{mg} / \mathrm{L}$ in treatments D200, D100 and D50, respectively (Figure $3)$.

\subsection{Shrimp growth performance and feed uti- lization}

The results of the effect of stocking density on growth performance and feed utilization of whiteleg shrimp at three stocking densities are exhibited in Table 3. Average individual final body weight was reduced $(P<0.05)$ as stocking density increased (Table 3 ). The biweekly body weight of shrimp under three stocking densities is shown in Figure 4. At the end of the trial, the average final body weights of shrimp were 7.05 , 6.83 and $6.24 \mathrm{~g} / \mathrm{shrimp}$ at a density of 50,100 and $200 \mathrm{shrimp} / \mathrm{m}^{2}$, respectively.

Significant differences for WG and SGR were found among the density treatments $(P<0.05)$. The WG of shrimp were $0.777,0.771$ and 0.766 $\mathrm{g} / \mathrm{shrimp} /$ week at 50, 100 and $200 \mathrm{shrimp} / \mathrm{m}^{2}$, respectively, with significant differences $(P<$ 
Table 3. Effects of stocking densities on the shrimp performance of L. vannamei during the study

\begin{tabular}{lccc}
\hline \multirow{2}{*}{ Parameters } & \multicolumn{3}{c}{ Treatment } \\
\cline { 2 - 4 } & $\mathrm{D} 50$ & $\mathrm{D} 100$ & $\mathrm{D} 200$ \\
\hline Initial body weight (g/shrimp) & $0.83 \pm 0.02^{\mathrm{a} \dagger}$ & $0.84 \pm 0.02^{\mathrm{a}}$ & $0.84 \pm 0.02^{\mathrm{a}}$ \\
Final body weight (g/shrimp) & $7.05 \pm 0.20^{\mathrm{a}}$ & $6.83 \pm 0.34^{\mathrm{ab}}$ & $6.24 \pm 0.27^{\mathrm{bc}}$ \\
WG (g/week) & $0.777 \pm 0.026^{\mathrm{a}}$ & $0.771 \pm 0.03^{\mathrm{ab}}$ & $0.766 \pm 0.022^{\mathrm{bc}}$ \\
SGR (\%/day) & $3.81 \pm 0.07^{\mathrm{a}}$ & $3.79 \pm 0.07^{\mathrm{ab}}$ & $3.76 \pm 0.02^{\mathrm{bc}}$ \\
Survival rate (\%) & $80.0 \pm 7.2^{\mathrm{a}}$ & $70.3 \pm 5.5^{\mathrm{ab}}$ & $61.0 \pm 7.8^{\mathrm{bc}}$ \\
FCR & $1.58 \pm 0.12^{\mathrm{a}}$ & $1.72 \pm 0.12^{\mathrm{ab}}$ & $1.96 \pm 0.13^{\mathrm{bc}}$ \\
\hline
\end{tabular}

$\dagger$ Values represent the mean $\pm \mathrm{SD}(\mathrm{n}=3)$.

Mean values in the same row with different superscript letters differ significantly (results from one-way measure ANOVA, Duncan test, $P<0.05)$.

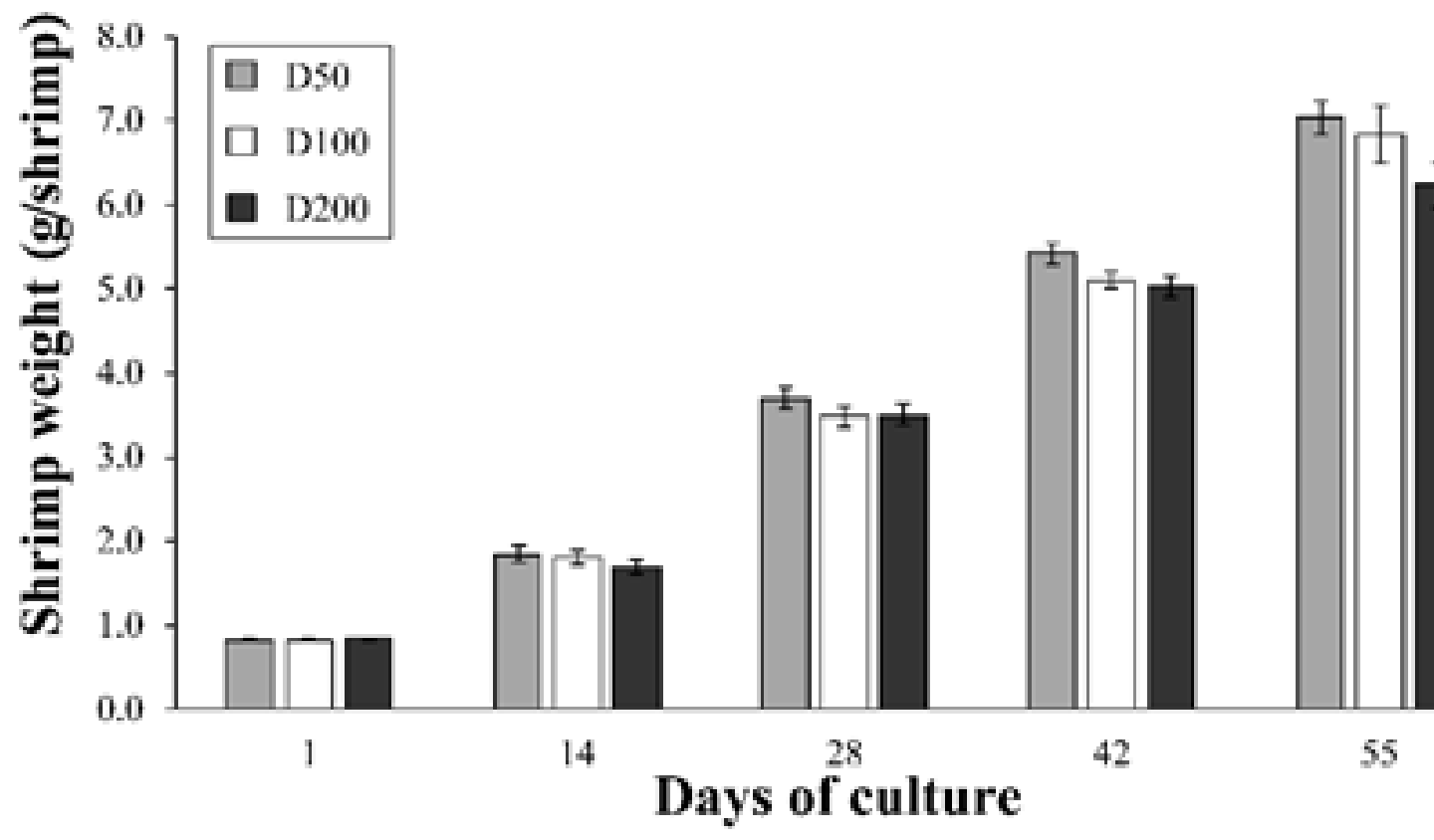

Figure 4. Effects of stocking densities on shrimp performance in the culture of L. vannamei during the study. Values are means and standard deviations at sampling times $(\mathrm{n}=3)$.

$0.05)$ between stocking densities. Average values of SGR were 3.81, 3.79 and $3.76 \%$ /day at 50, 100 and $200 \mathrm{shrimp} / \mathrm{m}^{2}$, respectively, with significant differences among stocking densities $(P<0.05)$.

These data indicated that growth performance was declined by increasing the density of shrimp. These results were similar to those mentioned by several authors, who found that growth in $L$. vannamei and other penaeid species is stocking density-dependent (Moss \& Moss, 2004; Yu et al., 2009; Arambul-Muñoz et al., 2019). The growth performance of shrimp in this study was lower than that recorded by other authors, who found that, at stocking densities ranging of 17 -
$45 \operatorname{shrimp} / \mathrm{m}^{2}$, and $40-80 \mathrm{shrimp} / \mathrm{m}^{2}$, L. vannamei juvenile can grow between 20.70 to 25.25 $\mathrm{g} /$ shrimp, and 12.4 and $16.5 \mathrm{~g} /$ shrimp, respectively (Sookying et al., 2011; Nguyen et al., 2013). However, in these works, the density - dependent growth was comparable, although there were differences in shrimp growth. These variations might be due to factors like environmental conditions, origin, size of organisms, experimental unit size, study periods, and culture systems.

In this work, survival rates of the whiteleg shrimp were 80.0, 70.3 and $61.0 \%$ at 50,100 and 200 shrimp $/ \mathrm{m}^{2}$, respectively (Table 3 ). Values of survival rates decreased significantly $(P$ 
$<0.05)$ with increasing shrimp density. However, the differences between the density of 50 and $100 \mathrm{shrimp} / \mathrm{m}^{2}$, and so among 100 and 200 shrimp $/ \mathrm{m}^{2}$ were not significant $(P>0.05)$. These values of survival rates are economically, technically good, acceptable and agree with those observed by Neal et al. (2010) for zero-exchange mixed biofloc systems with a survival rate of 61.8 - $89.8 \%$. Nguyen et al. (2013) found that increasing density of whiteleg shrimp from 40 to 80 shrimp $/ \mathrm{m}^{2}$ caused in negligible but significant $(P$ $<0.05)$ declines in survival. On the other hand, Sookying et al. (2011) found that shrimp survival was high $(>93.4 \%)$ and unaffected by increasing stocking density of L. vannamei from 17 to 45 shrimp $/ \mathrm{m}^{2}$. The same trend was obtained by Allan \& Maguire (1992) using shrimp densities from 5 to 40 shrimp $/ \mathrm{m}^{2}$ of $P$. monodon.

The average values of FCR were 1.58, 1.72 and 1.96 at 50, 100 and $200 \mathrm{shrimp} / \mathrm{m}^{2}$, respectively (Table 3). Values of FCR significantly increased $(P<0.05)$ with increased shrimp density. The results of this study agreed with the previous publications under the same conditions. There was a negative correlation between stocking density and FCR with FCR ranging from $1.15-2.77$ for L. vannamei and other penaeid species (Martin et al., 1998; Zaki et al., 2004; Sookying et al., 2011).

\section{Conclusions}

Under the experimental conditions of this work, as stocking density increased from 50 to 200 shrimp $/ \mathrm{m}^{2}$, certain parameters of water quality worsened almost linearly. Moreover, there was an obvious density-dependent relationship that revealed a decline in growth rate (final body weight, WG, and SGR), survival and increase in FCR as stocking density increased. From the abovementioned results, it could be concluded that with increasing the stocking density the production of shrimp increased but in a low final weight and survival compared to low stocking density. This problem also highlights the economic risks related to increasing stocking densities.

\section{Conflict of interest declaration}

The authors have no conflicts of interest to declare. All co-authors have seen and agree with the contents of the manuscript.

\section{Acknowledgements}

The study was funded by Nong Lam University (Grant no. CS - CB16 - TS - 01).

\section{References}

Allan, G. L., \& Maguire, G. B. (1992). Effects of stocking density on production of Penaeus monodon Fabricius in model farming ponds. Aquaculture 107(1), 49-66.

APHA (American Public Health Association). (2012). Standard methods for the examination of water and wastewater $\left(22^{\text {nd }}\right.$ ed.). Washington, USA: American Public Health Association.

Arambul-Muñoz, E., Ponce-Palafox, J. T., Santos, R. C. D. L., Aragón-Noriega, E. A., Rodríguez-Domínguez, G., \& Castillo-Vargasmachuca, S. G. (2019). Influence of stocking density on production and water quality of a photoheterotrophic intensive system of white shrimp (Penaeus vannamei) in circular lined grow-out ponds, with minimal water replacement. Latin American Journal of Aquatic Research 47, 449-455.

Arnold, S. J., Coman, F. E., Jackson, C. J., \& Groves, S. A. (2009). High-intensity, zero water-exchange production of juvenile tiger shrimp, Penaeus monodon: An evaluation of artificial substrates and stocking density. Aquaculture 293(1), 42-48.

Avnimelech, Y., \& Ritvo, G. (2003). Shrimp and fish pond soils: processes and management. Aquaculture 220 (14), 549-567.

Boopathy, R., Bonvillain, C., Fontenot, Q., \& Kilgen, M. (2007). Biological treatment of low-salinity shrimp aquaculture wastewater using sequencing batch reactor. International Biodeterioration \& Biodegradation 59(1), 16-19.

Boyd, C. E., \& Tucker, C. S. (1998). Pond aquaculture water quality management. New York, USA: Springer Science+Business Media.

Chen, S., Ling, J., \& Blancheton, J. P. (2006). Nitrification kinetics of biofilm as affected by water quality factors. Aquacultural Engineering 34(3), 179-197.

Ebeling, J. M., Timmons, M. B., \& Bisogni, J. J. (2006). Engineering analysis of the stoichiometry of photoautotrophic, autotrophic, and heterotrophic removal of ammonia-nitrogen in aquaculture systems. Aquaculture 257(1-4), 346-358.

Furtado, P. S., Campos, B. R., Serra, F. P., Klosterhoff, M., Romano, L. A., \& Wasielesky, W. (2015). Effects of nitrate toxicity in the Pacific white shrimp, Litopenaeus vannamei, reared with biofloc technology (BFT). Aquaculture International 23(1), 315-327.

Gomez, K. A., \& Gomez, A. A. (1984). Statistical procedures for agricultural research ( $2^{\text {nd }}$ ed.). New Jersey, USA: John Wiley \& Sons. 
Kuhn, D. D., Smith, S. A., \& Flick, G. J. (2011). High nitrate levels toxic to shrimp: Toxicity more of an issue in lower-salinity waters. Global Aquaculture Advocate. Global Aquaculture Alliance.

Legarda, E. C., Barcelos, S. S., Redig, J. C., Ramírez, N. C. B., Guimarães, A. M., Santo, C. M. d. E., Seiffert, W. Q., \& Vieira, F. d. N. (2018). Effects of stocking density and artificial substrates on yield and water quality in a biofloc shrimp nursery culture. Revista Brasileira de Zootecnia 47, e20170060.

Lin, Y. C., \& Chen, J. C. (2003). Acute toxicity of nitrite on Litopenaeus vannamei (Boone) juveniles at different salinity levels. Aquaculture 224(1-4), 193-201.

Lin, Y. C., \& Chen, J. C. (2001). Acute toxicity of ammonia on Litopenaeus vannamei Boone juveniles at different salinity levels. Journal of Experimental $M a$ rine Biology and Ecology 259(1), 109-119.

MARD (Ministry of Agriculture and Rural Development). (2014). QCVN 02 - 19 : 2014/BNNPTNT. $N a-$ tional technical regulation on brackish water shrimp culture farm - Conditions for veterinary hygiene, environmental protection and food safety. Ha Noi, Vietnam: MARD.

Martin, J. L. M., Veran, Y., Guelorget, O., \& Pham, D. (1998). Shrimp rearing: stocking density, growth, impact on sediment, waste output and their relationships studied through the nitrogen budget in rearing ponds. Aquaculture 164(1), 135-149.

Moss, K. R. K., \& Moss, S. M. (2004). Effects of artificial substrate and stocking density on the nursery production of Pacific white shrimp Litopenaeus vannamei. Journal of the World Aquaculture Society 35(4), 536542.

Neto, A. I., Brandão, H., Furtado, P. S., \& Wasielesky Jr, W. (2019). Acute toxicity of nitrate in Litopenaeus vannamei juveniles at low salinity levels. Ciencia Rural 49, e20180439.

Nguyen, P. T., Vu, V. S., Nguyen, V. V., Nguyen, Q. T., Dang, T. D., Doan, T. N., Tran, T. M., \& Vu, V. I. (2013). Effect of stocking density on growth rate and survival of white leg shrimp, Litopenaeus vannamei, raised on indoor composite tanks. Journal of Science and Development 11(2), 223-229.
Nguyen, T. V., Nguyen, T. P. C., \& Nguyen, K. H. N. (2019). Roles of research and education in freshwater aquaculture development: A case of striped catfish farming in Viet Nam. In Figus, A., and Potempa, T. (Eds.). Bologna process and fisheries education for sustainable development (143-162). Roma, Italy: Eurilink University Press.

Sahu, B. C., Adhikari, S., \& Dey, L. (2013). Carbon, nitrogen and phosphorus budget in shrimp (Penaeus monodon) culture ponds in eastern India. Aquaculture International 21 (2), 453-466.

Sookying, D., Silva, F. S. D., Davis, D. A., \& Hanson, T. R. (2011). Effects of stocking density on the performance of Pacific white shrimp Litopenaeus vannamei cultured under pond and outdoor tank conditions using a high soybean meal diet. Aquaculture 319(1), 232239.

Valencia-Castañeda, G., Frías-Espericueta, M. G., Vanegas-Pérez, R. C., Chávez-Sánchez, M. C., \& PáezOsuna, F. (2019). Toxicity of ammonia, nitrite and nitrate to Litopenaeus vannamei juveniles in low-salinity water in single and ternary exposure experiments and their environmental implications. Environmental Toxicology and Pharmacology 70, 103193.

Wyk, P. V., \& Scarpa, J. (1999). Water quality requirements and management. In Wyk, P. V., Davis Hodgkins, M., Laramore, R., Main, K. L., Mountain, J., and Scarpa, J. (Eds.). Farming marine shrimp in recirculating freshwater systems (141-162). Florida, USA: Florida Department of Agriculture and Consumer Services.

Yu, R., Leung, P., \& Bienfang, P. (2009). Modeling partial harvesting in intensive shrimp culture: A network-flow approach. European Journal of Operational Research 193 (1), 262-271.

Zaki, M. A., Nour, A. A., Abdel-Rahim, M. M., \& Srour, T. M. (2004). Effect of stocking density on survival, growth performance, feed utilization and production of marine shrimp Penaeus semisulcatus in earthen ponds. Egyptian Journal of Aquatic Research 30(B), 429-442. 